\title{
ANÁLISIS DE LA POLÍTICA PÚBLICA DE REINTEGRACIÓN SOCIAL Y ECONÓMICA EN EL MARCO DEL PROCESO DE JUSTICIA TRANSICIONAL EN COLOMBIA PERIODO 2013-2014
}

Analysis of the Public Policy of Social and Economic Reintegration in the Framework of the Transitional Justice Process in Colombia 2013-2014 Period

$\underline{\text { Sixta Dilia Zúñiga Lindao }}^{1}$

Fecha de recepción: 20 de octubre de 2016

Fecha de aceptación: 13 de diciembre de 2016

SUMARIO: 1. Introducción; 2. Sobre la justicia transicional; 3. Los nuevos estándares de justicia; 3.1 Derecho a la verdad; 3.2 Derecho a la justicia; 3.3 Derecho a la reparación; 3.4 Garantía de no repetición; 4. Conclusiones; 5. Recomendaciones; 6 . Referencias bibliográficas.

\footnotetext{
1 Abogada de la Universidad Autónoma Latinoamericana, magister en Derecho Administrativo de la Universidad Libre, Especialista en Derecho Administrativo de la Universidad Militar Nueva Granada, Especialista en Gerencia Pública de la Corporación Universitaria del Caribe. Con experiencia profesional aproximada de 15 años en el sector público, ocupando distintos cargos, tales como; Personera del municipio de Uribia La Guajira, Asesora jurídica en el Ministerio de Defensa Nacional y en la actualidad como Asesora de la Comisión Nacional del Servicio Civil. Cuenta con experiencia docente en el área de Derechos Humanos y Derecho Internacional Humanitario. Correo-e: sixta.1980@hotmail.com y szuniga@cnsc.gov.co
} 


\section{COMO CITAR ESTE ARTÍCULO (APA 6)}

Zúñiga Lindao, Sixta Dilia (2017). Análisis de la política pública de reintegración social y económica en el marco del proceso de justicia transicional en Colombia. Periodo 2013-2014. Revista Jurídica Mario Alario D’Filippo, IX (17), pág. 95-131.

\section{RESUMEN}

En el marco del proceso de paz, es perentorio realizar un análisis consistente de las diversas discusiones y posiciones de la sociedad con el fin de desarrollar un proceso integratorio. Para ello, es importante realizar un estudio histórico enfocándose en los orígenes, desarrollo y métodos implementados para desarrollar una buena política pública de esta temática en medio de conflictos anteriores. Es aquí precisamente donde enfocaremos nuestra investigación, pero no sin antes, tomar como punto de partida las teorías sobre la justicia transicional, seguido de esto, estudiaremos las distintas políticas públicas que se han desempeñado en Colombia sobre los procesos de paz y la propuesta actual del gobierno que se enlaza con elementos de la justicia transicional para buscar la reintegración social, y por último, se hará una exposición de las necesarias transformaciones o modificaciones que se deben surtir al interior de la política pública estatal de reintegración social procurando un buen éxito del proceso.

\section{PALABRAS CLAVES}

Justicia transicional, política pública, reintegración, grupos armados, paz, posconflicto.

\section{ABSTRACT}

Within the framework of the peace process, it is imperative to carry out a consistent analysis of the various discussions and positions of society in order to develop an integrative process. For this, it is important to carry out a historical study focusing on the origins, development and methods implemented to develop a good public policy of this subject in the middle of previous conflicts. It is here precisely where we will focus our research, but not before, take as a starting point theories on transitional justice, followed by this, we will study the different public policies that have been carried out in Colombia on the peace processes and the current proposal of the A government that is linked to elements of transitional justice to seek social reintegration, and finally, an exposition of the necessary transformations or modifications that must be provided within the state public policy of social reintegration seeking a successful process.

\section{KEYWORDS}

Transitional justice, Public Policy, Reintegration, Armed Groups, Peace, Post-Conflict. 


\section{INTRODUCCION}

La puesta en marcha de un nuevo proceso de paz en un marco normativo propio de la justicia transicional plantea retos, interrogantes y discusiones que deben ser mirados individualmente y tratados cada uno en formas diversas, y aún armónicas en cuanto a los fines perseguidos por los actores armados, y la misma sociedad civil.

En tal sentido, el rigor y la disciplina investigativa nos conminan siempre a tomar el estudio histórico de estos procesos como punto de partida, abarcando matices concernientes a sus orígenes, desarrollo y métodos implementados para lograr soluciones apropiadas correspondientes al diseño de un esquema de políticas públicas dentro de los procesos de justicia transicional.

Para abarcar con suficiencia este punto de partida, se invitará al lector a hacer una consistente retroalimentación respecto de la justicia transicional, tomando como asidero su evolución histórica, los estándares de justicia y en especial los principios que la fundamentan, desde donde será analizada la relación que confluye entre el derecho administrativo, las políticas públicas y por supuesto la justicia transicional.

A continuación, se brindará al lector una visión amplia y detallada sobre las políticas públicas que se han formulado en Colombia, en repuesta a los problemas generados por los conflictos sociales y/o armados presentados en el territorio nacional, partiendo para ello desde los lineamientos generales que fija el Plan Nacional de Desarrollo, los documentos CONPES y los programas y proyectos de gobierno que se ejecutan para lograr la consolidación de la paz y la reconstrucción del tejido social.

Interiorizados los aspectos anteriormente mencionados, la investigación propuesta posará su atención sobre la actual política pública para la reintegración social y económica de los grupos armados al margen de la ley, realizando un análisis de su formulación y aplicación en el marco del actual proceso de justicia transicional que se vive en Colombia, partiendo para ello de los procesos de auditoria y evaluación realizados recientemente por entes de control estatal y del cumplimiento de los objetivos de la política.

Por último, se hará una exposición de las necesarias transformaciones o modificaciones que se deben surtir al interior de la política pública estatal de reintegración social - a título de propuestas- en procura de su funcionalidad hacia la consecución de cada una de las finalidades que propone la experiencia de la justicia transicional y el éxito del proceso.

\section{SOBRE LA JUSTICIA TRANSICIONAL}

"La última y definitiva justicia, es el perdón" Miguel de Unamuno (1864-1936). 
El concepto de justicia transicional es tan novel, que su denominación última y definitiva cobró valor no hace mucho tiempo. Al respecto, Orozco Abad nos enseña que "(...) la expresión justicia transicional debió competir con otras, como, por ejemplo, con la expresión justicia retrospectiva, por el mercado de las fórmulas consagradas. En el año 2000 se publicó el libropionero de RUTI TEITEL con el mismo nombre, pero solo con la compilación en tresvolúmenes de Neil Kritz, TransitionalJustice, la expresión triunfó sobre sus pares y llegó a generalizarse".

Benavides Vanegas amplía sobre el tema, al señalar que "El término surgió por primera vez con referencia a los procesos de transición a la democracia en Europa Central y en América Central que tuvieron lugar desde finales de los años 1980s y la primera parte de 1990s. se pretendía dar cuenta de la transición del régimen político y de su relación con la justicia, esto es, se intentaba dar respuesta a la pregunta de cómo los regímenes que sucedían a un régimen autoritario daban cuenta de las graves violaciones a los derechos humanos"

En similar sentido, Benavides Vanegas afirma que "La justicia transicional es un campo académico y de políticas públicas que está en continua expansión. Las políticas de transición se han aplicado en diversas regiones del mundo y en países con diferentes ideologías con el fin de hacer frente a un pasado de gobiernos autoritarios y de graves violaciones a los derechos humanos y al derecho internacional humanitario".

Tenido en cuenta lo anterior, debe recordarse que solamente el paso de tiempo, el aporte de estudios, experiencias, publicaciones y discusiones al respecto, han procurado que la justicia transicional haya ido alcanzando un nivel de madurez creciente, no hallándose una conceptualización única respecto del mismo.

Es así como el Centro Internacional para la Justicia Transicional, define: "La justicia transicional es el conjunto de medidas judiciales y políticas que diversos países han utilizado como reparación por las violaciones masivas de derechos humanos. Entre ellas figuran las acciones penales, las comisiones de la verdad, los programas de reparación y diversas reformas institucionales".

No obstante la definición anterior, su amplitud no insinúa siquiera el ámbito de aplicación de este mecanismo, algunos autores, en similares términos, conducen el concepto por sendas similares, procurando -eso sí- darle un ámbito local a la aplicabilidad de la misma.

Es así como el autorUprimny Yepes nos indica que “(...) la expresión 'justicia transicional' hace referencia a los procesos a través de los cuales se realizan transformaciones radicales en un orden social y político, bien sea por el paso de un régimen dictatorial a uno democrático, bien por la finalización de un conflicto interno armado y la consecución de la paz". 
En similar línea discursiva, más no idéntica, el doctrinante Torregrosa Jiménez nos señala que "La justicia transicional hace referencia a un problema muy antiguo, relativo a qué debe hacer una sociedad frente al legado de crímenes de lesa humanidad, cuando sale de una guerra civil o de un régimen tiránico".

Enbreve comparación, ambos conceptos apuntan hacia un ámbito local y atienden aspectos bien sean políticos, ora de conflicto civil; más no confluyen en cuanto a las consecuencias, por tanto que Uprimny se decanta por la transformación social producto de los procesos que implica la justicia transicional, en tanto que Torregrosa apunta hacia el rastro de sangre y sufrimiento que supone la entrada en escena de los crímenes de lesa humanidad.

Ambos conceptos, son en tanto aceptables como definitivamente complementarios, por tanto cada conceptualización atiende a aspectos que tocan al otro, sin sobreentenderse -hasta este punto- implícito en ellos los aspectos donde no convergen.

Por su parte, la Corte Constitucional, en sentencia C - 579 de 2013, indica que "La justicia transicional busca solucionar las fuertes tensiones que se presentan entre la justicia y la paz, entre los imperativos jurídicos de satisfacción de los derechos de las víctimas y las necesidades de lograr el cese de hostilidades. Para ello es necesario conseguir un delicado balance entre ponerle fin a las hostilidades y prevenir la vuelta a la violencia (paz negativa) y consolidar la paz mediante reformas estructurales y políticas incluyentes (paz positiva)".

Siguiendo con Torregrosa, acercándose más a la definición brindada por Uprimny, continúa apuntalando el concepto al indicar que “(...) tal y como se comprende en la actualidad, la justicia transicional hace referencia a aquellos procesos transicionales mediante los cuales se llevan a cabo transformaciones radicales de un orden social y político determinado, que enfrentan la necesidad de equilibrar las exigencias contrapuestas de paz y justicia".

Por otra parte, Mora Insuasty confirma la comunión de uno y otro concepto, tomando prestados lo definido por Uprimny con el Informe del Secretario General de Naciones Unidas, del 3 de agosto de 2004, definiendo a este tipo de justicia al precisar que “(...) esta propone un conjunto de medidas excepcionales que permiten garantizar la transición de un estado anormal de violencia hacia un orden social y político estable, logrando así un equilibrio en aras de alcanzar la paz y la reconciliación, sin tolerar la impunidad en casos de violaciones masivas y sistemáticas de Derechos Humanos. Esta transición busca superar el conflicto, y servir a la justicia en pro de la reconciliación social".

Así las cosas, y no sirviendo de beneplácito a los horrores que suponen las confrontaciones armadas, podemos tener la seguridad de que estos emergentes y únicos en sí mismos modelos de justicia, que atienden cada uno a una realidad social, jurídica, geográfica e 
histórica diferentes (a excepción de -por citar un ejemplo- el caso de Núremberg), son habitualmente implementados e instrumentalizados no tanto ante la confesa incapacidad de doblegar por la vía armada al contrario, sino por proteger a la población civil de la continuidad de las hostilidades.

Autores como Orozco Abad y Andreas Forer, coinciden en afirmar que Elster fue el primero en aseverar que los antecedentes más remotos de modelo de justicia transicional los encontramos en Atenas, en los años 411 y 403 a.C., dándose el primero con la derrota de ciertos gobiernos oligárquicos, con la consecuente restauración de la democracia perdida bajo su poder; y el segundo, con la finalización de las guerras del Peloponeso, con el derrocamiento del gobierno de los treinta tiranos, cuyo tratamiento fue más clemente que el dispensado en el 411.

Posteriormente, encontramos vestigios de justicia transicional en casos como el Edicto de Nantes (1598), firmado por Enrique IV de Francia, el cual zanjó el asunto de las guerras teológicas en su reinado, diciendo:

"Que la memoria de todos los acontecimientos ocurridos entre unos y otros tras el comienzo del mes de marzo de 1585 y durante los convulsos precedentes de los mismos, hasta nuestro advenimiento a la corona, queden disipados y asumidos como cosa no sucedida. No será posible ni estará permitido a nuestros procuradores generales, ni a ninguna otra persona pública o privada, en ningún tiempo, ni lugar, ni ocasión, sea esta la que sea, el hacer mención de ello, ni procesar o perseguir en ninguna corte o jurisdicción a nadie".

Ya en 1648, remembrando la Paz de Westfalia, que no sólo opera como vestigio de concertación en cuanto a soberanía y orden entre las naciones se refiere, encontramos un referente sólido, y aún rara vez visitado por parte de los autores que han abarcado el tema de la justicia transicional a través de la historia, por cuanto la mayoría se decanta por los juicios de Núremberg como primer punto de partida y referente.

En este aspecto, casamos con las posiciones que Orozco Abad sostiene en cuanto la importancia de este suceso histórico, pacificador, restaurador y creador de fuente legal de respeto por la soberaníade los Estados.

No obstante lo anterior, hay quienes consideran otros casos históricos anteriores, pero sin otorgarles relevancia alguna, como Valencia Villa, quien apunta que "Con excepción de dos episodios históricos muy peculiares, la caída de la oligarquía en la Atenas clásica, en 411 y 403 antes de Cristo, y la restauración de la monarquía en la Francia napoleónica, en 1814 y 1815, que por su antigüedad no pueden invocarse como precedentes, todas las experiencias de justicia transicional en sentido estricto se registran en nuestra época".

El motivo por el cual es de común asiento entre los estudiosos del tema señalar como punto de partida los juicios de Núremberg, es por el establecimiento del Tribunal 
Internacional Militar, inaugurando formal y definitivamente la era de la justicia trasnacional, especializada esta en materia penal. No obstante, autores como Rodolfo y Norhys Torregrosa Jiménez, remontan un poco la apuesta hacia atrás, señalando como punto de partida la Primera Guerra Mundial.

"Sus orígenes pueden remontarse a la Primera guerra Mundial ya que en ella se desatan un cúmulo de atrocidades que después van a ser reconocidas y juzgadas".

Previo a este nuevo escenario contencioso, el respeto de la soberanía de los estados, aún ante la presencia de crímenes de altísima entidad, era la regla general. Al respecto, y por rigurosidad jurídica, debemos recordar que es a partir de los juicios de Núremberg, y de la creación de la Organización de Naciones Unidas que se empieza a delinear y a perfeccionar el concepto de derechos humanos tal como se maneja hoy en día, categorizando y dando niveles de relevancia o ligereza a los derechos, obligaciones y valores jurídicos que en su generalidad componen el panorama jurídico actual en la institucionalidad jurídica de la mayoría de los Estados miembros.

Retornando al tema, se recuerda al Acuerdo de Londres, suscrito en 1945, como el punto de partida de uno de los tribunales ad hoc más relevantes en la historia universal. La ciudad de Núremberg retumba en la memoria y en la conciencia universal no solamente por darle nombre a los juicios donde se juzgaron a los más relevantes actores del nacionalsocialismo alemán, sino por la creación del concepto de "crímenes contra la humanidad", la extensión del principio de responsabilidad individual y la obligación de perseguir, y crear las instancias adecuadas para sancionar a nivel internacional estos crímenes.

Si bien es cierto que estos avances legados desde Núremberg prestan los elementos claves para estudio, alcance y delimitación de lo que se conoce ahora y para la posteridad como derechos humanos, quepa acotar que en dicho tribunal se hizo mayor inflexión en cuanto a los crímenes de guerra, quedando el consenso definitivo para darle un nuevo aire al concepto de estas altas prerrogativas, a los alcances que se observaron con la declaración universal de derechos humanos.

Otro tribunal de paralela importancia, muy poco visitado por parte de los doctrinantes, es el que tuvo lugar en Tokio entre 1946 y 1948, donde fueron juzgados los altos mandos japoneses ahí encontrados.

Ambos tribunales formularon sus imputaciones como crímenes contra la paz y crímenes de guerra; crímenes contra la humanidad; genocidio y; complot de guerra.

No obstante la relevancia de estos tribunales ad hoc, es inevitable encontrar hechos de guerra que en los mismos no fueron juzgados, y que marcaron indefectiblemente la historia por su magnífica potencia destructiva, más el arrebato de cientos de miles 
de vidas. Nos referimos, por citar vagos ejemplos, a los bombardeos de Hiroshima y Nagasaki, y por supuesto, a los experimentos con agentes químicos y biológicos sobre ciudadanos chinos durante la ocupación japonesa. Dichos antecedentes, relegados al olvido por parte de los estrados judiciales, nos demuestran tanto que la historia es escrita por los vencedores, como que los tribunales ad hoc tienen un propósito único, y por ende, un direccionamiento unívoco sobre cuyo designio no tienden a decepcionar, ni a dejar piedra sin levantar.

El segundo pilar en cuanto a justicia transicional, lo encuentran algunos autores, tales como López Díaz (y otros) en la fase de la posguerra fría, la cual "se asocia con la ola de transiciones hacia la democracia y modernización que comenzó en 1989”

Dicha fase, aunque etérea y difícil de observar con base en hechos conexos, es defendida por Rodolfo y Norhys Torregrosa, quienes comentan que dicha fase "(...) se caracteriza por el modelo restaurativo que se basa en levantar una historia a partir de los abusos sufridos en el pasado y es por esto que se desarrolló una nueva institución conocida como las comisiones de la verdad con el fin de investigar, documentar y hacer públicos los abusos a los derechos humanos".

En contraposición, hay quienes no identifican a la posguerra fría como fase útil a la historia de la justicia transicional. Tal es el caso de Benavides Vanegas, para quien "Con posterioridad a los juicios de Núremberg la justicia internacional entró en un periodo de inactividad que sólo fue alterado con la creación de la Corte Penal Internacional en 1998".

Varios autores coinciden en las comisiones de la verdad como un tercer escalón de capital importancia para los anales que a diario se escriben a nivel mundial en cuanto ocupa a la justicia transicional.

Las define la organización Amnistía Internacional como “(...) organismos de investigación oficiales, temporales, no judiciales, encargados de indagar sobre una constante de abusos contra los derechos humanos, incluidos los crímenes contra el derecho internacional, y de determinar la verdad. La mayoría concluye su trabajo con un informe final en el que se recogen los resultados de la investigación y se formulan recomendaciones".

Dichas comisiones conforman una garantía cara y debida a las víctimas, tal es conocer de boca de los victimarios y demás actores del conflicto, la verdad sobre los hechos ocurridos, las razones que desembocaron sobre ellos y sus familias los hechos de violencia que les dejaron marcados.

El caso insigne de este modelo lo encontramos en la Comisión de la Verdad y la Reconciliación conformada en Sudáfrica, después de que se desmontó el régimen del apartheid. 
Como bien se sabe, dicho régimen sostuvo una política de segregación racial no solamente en sitios públicos, sino en cuanto a educación, prohibición de matrimonios interraciales, negación del voto para los ciudadanos de raza negra y monopolio del poder público por parte de la minoría blanca que colonizó dichas tierras.

En este proceso, de capital importancia para la historia del tema bajo estudio, se propició la confesión en audiencias públicas de la verdad de los hechos, basándose en narraciones efectuadas por los mismos actores armados de frente a las víctimas y/o sus familiares afectados. El peso de conceder o no el perdón se tornó en decisión privada y exclusiva de las víctimas, dejando de lado la tradicional figura del tercero indiferente que supone la presencia de un juez.

No obstante la sempiterna máxima del arzobispo Desmond Tutú, de acuerdo con la cual "Sin perdón no hay futuro, pero sin confesión no puede haber perdón", muchos sostienen que en el proceso terminó garantizándosele impunidad a confesos criminales de homicidios, secuestro y desaparecimiento forzado; aunque otro amplio sector señala que es un caso sin precedentes, puesto que garantizó el conocimiento de la verdad de los hechos ocurridos, indemnizaciones para las víctimas directas e indirectas de tales horrendos crímenes, y sembró un muy importante precedente, útil para ser tomado como garantía de no repetición.

Al respecto, Benavides Vanegas señala: "En el caso surafricano se privilegió la verdad y la reconciliación por encima de la justicia penal, dando así lugar a un debate entre estos dos modelos de intervención en caso de transición. Sin embargo, las investigaciones recientes plantean serias dudas acerca del potencial reconciliador de la Comisión de la Verdad y, en su lugar, la critican por ser un factor generador de impunidad". Ob. Cit. p 22.

Es así como organizaciones como Amnistía Internacional, al abordar el tema de estas particulares comisiones, indica que su ámbito de aplicación se extiende hacia víctimas de genocidio, crímenes de lesa humanidad, crímenes de guerra, tortura, ejecución extrajudicial y desaparición forzada; todos estos delitos de alto impacto, cuyo delineamiento -como se venía comentando- toma fuerza y alcance a partir de los juicios de Núremberg.

Tal relevancia han tomado estas comisiones, que su establecimiento y puesta en marcha se ha verificado en múltiples países alrededor del mundo, entre los cuales contamos los siguientes:

- Bolivia (Comisión Nacional de Investigación de Desaparecidos Forzados, 1982)

- Argentina (Comisión Nacional sobre la Desaparición de Personas, 1983)

- Uganda (Comisión de Investigación sobre la Desaparición de Personas en Uganda, 1974, y Comisión de Investigación sobre las Violaciones de los Derechos Humanos, 1986) 
- Nepal (Comisión de Investigación para Localizar a Personas Desaparecidas durante el Periodo Panchayat, 1990)

- Chad (Comisión de Investigación de los Crímenes y Malversaciones Cometidos por el ex Presidente Habré, sus Coautores y/o Cómplices, 1991)

- Alemania (Comisión de Investigación en el Bundestag alemán para Tratamiento del Pasado y las Consecuencias de la Dictadura del SED en Alemania, 1992)

- El Salvador (Comisión de la Verdad, 1992)

- Sri Lanka (Comisión Presidencial de Investigación sobre el Traslado o la Desaparición Involuntarios de Personas en las Provincias Occidental, Meridional y de Sabaragamuwa; Comisión Presidencial de Investigación sobre el Traslado o la Desaparición Involuntarios de Personas en las Provincias del Centro, del Noroeste, del Centro Septentrional y de Uva; y Comisión Presidencial de Investigación sobre el Traslado o la Desaparición Involuntarios de Personas en las Provincias Septentrional y Oriental, 1994)

- Sudáfrica (Comisión de la Verdad y la Reconciliación, 1995)

- Haití (Comisión Nacional de la Verdad y la Justicia, 1995)

- Guatemala (Comisión para el Esclarecimiento Histórico de las Violaciones a los Derechos Humanos y los Hechos de Violencia que han Causado Sufrimientos a la Población Guatemalteca, 1997)

- Nigeria (Comisión para la Investigación de las Violaciones de Derechos Humanos, 1999)

- Chile (Comisión Nacional de Verdad y Reconciliación, 1990; Comisión Nacional sobre Prisión Política y Tortura, 2003)

- Corea del Sur (Comisión Presidencial para el Esclarecimiento de Muertes Acaecidas en Circunstancias Sospechosas, 2000)

- Perú (Comisión de la Verdad y Reconciliación, 2000)

- Uruguay (Comisión Investigadora sobre la Situación de Personas Desaparecidas y Hechos que la Motivaron, 1985, y Comisión para la Paz, 2000)

- Granada (Comisión de la Verdad y la Reconciliación, 2001) 
- Panamá (Comisión de la Verdad, 2001)

- República Federativa de Yugoslavia (Comisión de la Verdad y la Reconciliación, 2001)

- Sierra Leona (Comisión de la Verdad y Reconciliación, 2002)

- Timor Oriental (Comisión para la Acogida, la Verdad y la Reconciliación, 2002)

- Ghana (Comisión para la Reconciliación Nacional, 2002)

- Paraguay (Comisión de la Verdad y la Justicia, 2003)

- República Democrática del Congo (Comisión de la Verdad y la Reconciliación, 2003)

- Indonesia (Comisión de la Verdad y la Reconciliación, 2004)

- Marruecos (Comisión de Equidad y Reconciliación, 2004)

- Liberia (Comisión de la Verdad y la Reconciliación, 2005)

- Ecuador (Comisión “Verdad y Justicia”, 1996; Comisión de la Verdad, 2007).

La existencia de estas comisiones cobra genuina relevancia en otros aspectos cruciales para los regímenes democráticos, por cuanto también velan por encontrar y restablecer verdades que los regímenes represivos históricamente y a conveniencia buscan evitar y hacer desaparecer.

En tal sentido, la apuesta es a que la historia se escriba con concurso de todos los actores armados -incluyendo al Estado-, que no sea erradicada ni que su propósito se desvanezca en el tiempo. El riesgo que se correría si ello llegara a ocurrir es la pérdida de la memoria histórica, la cual, como se abordará debidamente a lo largo de este texto, juega un papel de insoslayable importancia para la conservación de la paz, y de las garantías de que los hechos detonantes de la violencia, su discurso y terminación, no se volverán a repetir.

\section{LOS NUEVOS ESTÁNDARES DE JUSTICIA}

Tal como ha quedado establecido a lo largo de esta discusión, hitos bélicos importantes como la guerra Franco-Prusiana y las dos Guerras Mundiales, generaron cuestionamientos e inquietudes respecto de la soberanía misma de los Estados en cuanto a su jurisdicción, entablando la necesidad de delimitar delitos de alto impacto, así como Cortes de alcance internacional que pudieran brindar justicia ante la ineficiencia o desinterés de los Estados. En suma, se busca satisfacer una -insatisfecha- necesidad de justicia retributiva. 
Es en tal sentido que los esfuerzos encaminados para acabar con la impunidad, garantizada en ciertas ocasiones por los mismos Estados, llevó en 1996 a que en el seno de la Organización de Naciones Unidas se publicara el informe denominado "La cuestión de la impunidad de los autores de violaciones de los derechos humanos (civiles y políticos)", del cual se formalizan las nuevas y actuales directrices a seguir en cuanto a la satisfacción de los derechos que le asisten a las víctimas.

Estos estándares quedan enmarcados para la posteridad como los componentes de la justicia transicional, es decir, el derecho a la verdad, la justicia, la reparación y la garantía de no repetición.

\subsection{DERECHO A LA VERDAD}

Con respecto al derecho de la verdad (sobre el cual se abrió previamente la discusión en cuanto se abarcó lo concerniente a las comisiones de la verdad), encontramos entre sus antecedentes históricos normativos lo dispuesto por el Protocolo I Adicional a los Convenios de Ginebra de 1949, relativo a la protección de las víctimas de los conflictos armados internacionales, de 1977, el cual hizo alusión directa al derecho a la verdad en los siguientes términos:

Artículo 32 - Principio general

En la aplicación de la presente Sección, las actividades de las Altas Partes contratantes, de las Partes en conflicto y de las organizaciones humanitarias internacionales mencionadas en los Convenios y en el presente Protocolo deberán estar motivadas ante todo por el derecho que asiste a las familias de conocer la suerte de sus miembros.

Siguiendo esta línea, el artículo 33 ídem detalla los procedimientos a observarse en el caso de los desaparecidos.

\section{Artículo 33 - Desaparecidos}

1. Tan pronto como las circunstancias lo permitan, y a más tardar desde el fin de las hostilidades activas, cada Parte en conflicto buscará las personas cuya desaparición haya señalado una Parte adversa. A fin de facilitar tal búsqueda, esa Parte adversa comunicará todas las informaciones pertinentes sobre las personas de que se trate.

2. Con objeto de facilitar la obtención de información de conformidad con lo dispuesto en el párrafo anterior, cada Parte en conflicto deberá, con respecto a las personas que no se beneficien de condiciones más favorables en virtud de los Convenios o del presente Protocolo:

a) registrar en la forma dispuesta en el artículo 138 del IV Convenio la información sobre tales personas, cuando hubieran sido detenidas, encarceladas o mantenidas en cualquier otra forma de cautiverio durante más de dos semanas como consecuencia de las hostilidades o de la ocupación o hubieran fallecido durante un período de detención; 
b) en toda la medida de lo posible, facilitar y, de ser necesario, efectuar la búsqueda y el registro de la información relativa a tales personas si hubieran fallecido en otras circunstancias como consecuencia de las hostilidades o de la ocupación.

3. La información sobre las personas cuya desaparición se haya señalado, de conformidad con el párrafo 1 , y las solicitudes de dicha información serán transmitidas directamente o por conducto de la Potencia protectora, de la Agencia Central de Búsqueda del Comité Internacional de la Cruz Roja, o de las Sociedades nacionales de la Cruz Roja (Media Luna Roja, León y Sol Rojos). Cuando la información no sea transmitida por conducto del Comité Internacional de la Cruz Roja y de su Agencia Central de Búsqueda, cada Parte en conflicto velará porque tal información sea también facilitada a esa Agencia.

4. Las Partes en conflicto se esforzarán por ponerse de acuerdo sobre disposiciones que permitan que grupos constituidos al efecto busquen, identifiquen y recuperen los muertos en las zonas del campo de batalla; esas disposiciones podrán prever, cuando proceda, que tales grupos vayan acompañados de personal de la Parte adversa mientras lleven a cabo esas misiones en zonas controladas por ella. El personal de tales grupos deberá ser respetado y protegido mientras se dedique exclusivamente a tales misiones.

Este antecedente, aplicable -ante todo- a las víctimas de desaparición forzada, comporta el punto de partida para el posterior aproximamiento normativo y jurisprudencial que se ha venido desarrollando y solidificando a través de los años. En tal sentido, no deben olvidarse los artículos 16 y 17del Convenio de Ginebra para aliviar la suerte que corren los heridos y los enfermos de las Fuerzas Armadas en campaña, del año 1949, que desarrollan y detallan procedimientos relevantes para sostener y documentar la suerte de heridos, enfermos y muertos de la parte contraria, lo cual sirve para edificar una verdad cara a las víctimas indirectas de la guerra, para la sociedad en general, y para la comunidad mundial.

Por otra parte, recordamos tambiénla declaración efectuada en el marco XXIV Conferencia Internacional de la Cruz Roja y de la Media Luna Roja, Manila, 1981, Resolución II, en la cual se resolvió que el Comité Internacional de la Cruz Roja Internacional:

Condena toda acción que dé lugar a desapariciones forzadas o involuntarias dirigidas o perpetradas por gobiernos, o en connivencia con los mismos o con su consentimiento; recomienda que el CICR tome todas las iniciativas apropiadas que permitan conocer la suerte corrida por las personas desaparecidas o prestar ayuda a sus familiares, e insta a que se conceda a la Agencia Central de Informaciones del CICR, así como a cualquier otra organización humanitaria imparcial, las facilidades necesarias para actuar eficazmente a este respecto;

insta a los gobiernos a que se esfuercen por impedir las desapariciones forzadas o involuntarias y a que emprendan y lleven a cabo encuestas pormenorizadas sobre cada caso de desaparición ocurrido en su territorio;

insta asimismo a los gobiernos a que colaboren con instituciones humanitarias, así como con los órganos de las Naciones Unidas y de las organizaciones intergubernamentales, en 
particular las que investigan las desapariciones forzadas o involuntarias, para tratar de poner fin a este fenómeno.

Tan pronto como las circunstancias lo permitan, y a más tardar desde el fin de las hostilidades activas, cada Parte en conflicto buscará las personas cuya desaparición haya señalado una Parte adversa. A fin de facilitar tal búsqueda, esa Parte adversa comunicará todas las informaciones pertinentes sobre las personas de que se trate.

De igual manera, es de capital importancia remitirnos - una y otra vez- a los Principios contra la Impunidad diseñados por Louis Joinet, quien al respecto detalla que el derecho a saber:

No se trata sólo del derecho individual que toda víctima o sus familiares tienen asaber lo que ocurrió, que es el derecho a la verdad. El derecho a saber es tambiénun derecho colectivo que hunde sus raíces en la historia, para evitar que puedanreproducirse en el futuro las violaciones. Como contrapartida, al Estado leincumbe, el «deber de recordar», a fin de protegerse contra esas tergiversacionesde la historia que llevan por nombre revisionismo y negacionismo; en efecto, elconocimiento por un pueblo de la historia de su opresión forma parte de supatrimonio y debe por ello conservarse. Tales son los principales objetivos delderecho a saber cómo derecho colectivo.

Otro fundamento importante respecto del derecho a la verdad lo encontramos en los Principios Rectores de los desplazamientos internos, detallando en su principio 16 lo siguientes:

\section{Principio 16}

1. Los desplazados internos tienen derecho a conocer el destino y el paradero de sus familiares desaparecidos.

2. Las autoridades competentes tratarán de averiguar el destino y el paradero de los desplazados internos desaparecidos y cooperarán con las organizaciones internacionales competentes dedicadas a esta labor. Informarán a los parientes más próximos de la marcha de la investigación y les notificarán los posibles resultados.

3. Las autoridades competentes procurarán recoger e identificar los restos mortales de los fallecidos, evitar su profanación o mutilación y facilitar la devolución de esos restos al pariente más próximo o darles un trato respetuoso.

4. Los cementerios de desplazados internos serán protegidos y respetados en toda circunstancia. Los desplazados internos tendrán derecho de acceso a los cementerios de sus familiares difuntos.

Teniendo en cuenta lo anterior, y centrando especial atención a los principios de Joinet, podemos inferir que el derecho a la verdad implica no solamente una deuda debida a las 
víctimas - directa y/o indirectas- de los conflictos, sino también una preciosa y minuciosa labor de preservar todos los elementos, tanto físicos como narrados, que puedan conservar la misma en el mejor estado de fidelidad posible, puesto que la verdad atañe de manera directa, o indirecta si se quiere, a la sociedad en general.

En tal sentido, conforme lo establece la doctrinante Tatiana Rincón, "Se trata de una verdad que, siguiendo a Ignatieff, podemos entender en dos dimensiones: factual, o el relato de lo que ocurrió, y moral, la narración que busca explicar el por qué de lo ocurrido, $y$, en esa medida, configura un juicio crítico sobre los hechos".

Es así como en 1995, la Comisión Interamericana de Derechos Humanos, en el marco del caso No. 10.580, publicó en su informe No. 10 de 1995, en el caso Manuel Stalin Bolaños Quiñonez vs Ecuador, motivado por desaparecimiento forzado, se abordó por primera vez el derecho a la verdad por parte de dicho ente investigador y acusador.

"El Gobierno de Ecuador no cumplió con su obligación de proporcionar un recurso sencillo, rápido y eficiente a la familia de la víctima, para que pudiesen determinarse sus derechos. La familia de Manuel Bolaños tiene derecho a saber la verdad sobre lo que le ocurrió, las circunstancias de su detención y de su muerte, y a saber dónde se encuentran sus restos. Esto emana de la obligación del Estado de hacer uso de todos los medios que tiene a su disposición para llevar a cabo una investigación seria sobre las violaciones cometidas dentro de su jurisdicción a efectos de identificar a los responsables".

Por otra parte, la Convención Americana Sobre Derechos Humanos, en sus artículos 8, 13 y 25 , plasma de manera un tanto indirecta el derecho a la verdad debido a las víctimas en los siguientes términos:

Artículo 8. Garantías Judiciales. 1. Toda persona tiene derecho a ser oída, con las debidas garantías y dentro de un plazo razonable, por un juez o tribunal competente, independiente e imparcial, establecido con anterioridad por la ley, en la sustanciación de cualquier acusación penal formulada contra ella, o para la determinación de sus derechos y obligaciones de orden civil, laboral, fiscal o de cualquier otro carácter.

\section{(...)}

f) derecho de la defensa de interrogar a los testigos presentes en el tribunal y de obtener la comparecencia, como testigos o peritos, de otras personas que puedan arrojar luz sobre los hechos;

\section{(...)}

Artículo 13. Libertad de Pensamiento y de Expresión. 1. Toda persona tiene derecho a la libertad de pensamiento y de expresión. Este derecho comprende la libertad de buscar, recibir y difundir informaciones e ideas de toda índole, sin consideración de fronteras, ya sea 
oralmente, por escrito o en forma impresa o artística, o por cualquier otro procedimiento de su elección.

$(\ldots)$

Artículo 25. Protección Judicial. 1. Toda persona tiene derecho a un recurso sencillo y rápido o a cualquier otro recurso efectivo ante los jueces o tribunales competentes, que la ampare contra actos que violen sus derechos fundamentales reconocidos por la Constitución, la ley o la presente Convención, aun cuando tal violación sea cometida por personas que actúen en ejercicio de sus funciones oficiales.

\title{
(...)
}

Con base en estas disposiciones, en la sentencia hito del caso Velásquez Rodríguez vs Honduras, del 29 de julio de 1988, la Corte Interamericana de Derechos Humanos hizo una aproximación no directa, pero sí tangencial, a la protección al derecho a la verdad, debido a la desaparición forzada del señor Velásquez Rodríguez en manos de agentes estatales.

\begin{abstract}
"En ciertas circunstancias puede resultar difícil la investigación de hechos que atenten contra derechos de la persona. La de investigar es, como la de prevenir, una obligación de medio o comportamiento que no es incumplida por el solo hecho de que la investigación no produzca un resultado satisfactorio. Sin embargo, debe emprenderse con seriedad y no como una simple formalidad condenada de antemano a ser infructuosa. Debe tener un sentido y ser asumida por el Estado como un deber jurídico propio y no como una simple gestión de intereses particulares, que dependa de la iniciativa procesal de la víctima o de sus familiares o de la aportación privada de elementos probatorios, sin que la autoridad pública busque efectivamente la verdad. Esta apreciación es válida cualquiera sea el agente al cual pueda eventualmente atribuirse la violación, aun los particulares, pues, si sus hechos no son investigados con seriedad, resultarían, en cierto modo, auxiliados por el poder público, lo que comprometería la responsabilidad internacional del Estado". Corte Interamericana de Derechos Humanos. Caso Velásquez Rodríguez vs Honduras. Sentencia de 29 de julio de 1988.
\end{abstract}

De igual manera, en el caso Barrios Altos vs Perú, en el cual hubo una presunta masacre por parte de agentes estatales sobre ciudadanos indefensos, la Corte Interamericana de Justicia resolvió admitir la responsabilidad internacional del Estado procesado (por cuanto hubo allanamiento a los hechos), declarándole culpable de violación del derecho a la vida de las víctimas, integridad personal, y a las garantías judiciales y protección judicial, contenidos en los reseñados artículos 8 y 25 de la Convención. En este caso, aunque no se alude directa y textualmente la protección de este derecho, sí se protegió y defendió de manera indirecta.

“47. En el presente caso, es incuestionable que se impidió a las víctimas sobrevivientes, sus familiares y a los familiares de las víctimas que fallecieron, conocer la verdad acerca de los 
hechos ocurridos en Barrios Altos.

48. Pese a lo anterior, en las circunstancias del presente caso, el derecho a la verdad se encuentra subsumido en el derecho de la víctima o sus familiares a obtener de los órganos competentes del Estado el esclarecimiento de los hechos violatorios y las responsabilidades correspondientes, a través de la investigación y el juzgamiento que previenen los artículos 8 y 25 de la Convención. 3

49. Por lo tanto, esta cuestión ha quedado resuelta al haberse señalado (supra párr. 39) que el Perú incurrió en la violación de los artículos 8 y 25 de la Convención, en relación con las garantías judiciales y la protección judicial". Corte Interamericana de Derechos Humanos. Caso Barrios Altos vs Perú. Sentencia del 14 de marzo de 2001.

En tal sentido, ha habido múltiples pronunciamientos, tanto por parte de la Corte, como de la Comisión, encaminados a proteger el derecho a la verdad. Algunos de los más relevantes han resultado en condenas para el Estado Colombiano.

De manera que la verdad, como punto de partida, comporta no solamente una satisfacción que debe perseguir incansablemente (para sí y para las víctimas) el aparato jurisdiccional y la sociedad misma, sino que es pilar fundamental para dejar a la posterioridad una base sólida que materialice una real garantía de no repetición.

Es desde este dimensionamiento de cada conflicto (las causas que lo desataron, conformadas por aspectos de tipo político, social, religioso, cultural, etc.; los hechos ocurridos durante el desarrollo del mismo, conformadas por las agresiones, violaciones de las reglas de derecho internacional humanitario, acciones tomadas en relación de los prisioneros, población civil, daños en infraestructuras, etc.; los hechos posteriores al conflicto, que comportan una delicada y crucial transición entre un ambiente de hostilidad plagado de confusión, irrespeto hacia los derechos de actores y no actores de la confrontación, etc.), que se podría eventualmente alcanzar a visualizar al mismo desde sus verdaderas proporciones, por cuanto antes de que se llegue a una reconstrucción de los hechos, con concurso de todos los actores, involucrados y sociedad en general, resulta imposible llegar a una verdad correctamente construida, sin visiones sesgadas de la misma, y plena de lecciones para nunca olvidar.

Nunca debe olvidarse aquel adagio creado para enseñarnos que la memoria debe preservarse, ante todo, y sobre todo: aquel que no conoce la historia, está condenado a repetirla.

\subsection{DERECHO A LA JUSTICIA}

En cuanto al derecho a la justicia, los principios 26 y 27 de Joinet entrañan lo siguiente: 
26. Implica que toda víctima tenga la posibilidad de hacer valer sus derechos beneficiándose de un recurso justo y eficaz, principalmente para conseguir que su opresor sea juzgado, obteniendo su reparación. Como se subraya en el preámbulo de la Estructura de principios, no existe reconciliación justa y durable sin que sea aportada una respuesta efectiva a los deseos de justicia; el perdón, acto privado, supone, en tanto que factor de reconciliación, que la víctima conozca al autor de las violaciones cometidas contra ella y el opresor esté en condiciones de manifestar su arrepentimiento; en efecto, para que el perdón pueda ser concedido, es necesario que sea solicitado.

27. El derecho a la justicia confiere al Estado una serie de obligaciones: la de investigar las violaciones, perseguir a sus autores y, si su culpabilidad es establecida, de asegurar su sanción. Si la iniciativa de investigar corresponde en primer lugar al Estado, las reglas complementarias de procedimiento deben prever que todas las víctimas puedan ser parte civil y, en caso de carencia de poderes públicos, tomar ella misma la iniciativa.

Partiendo de estos principios, podemos dimensionar el derecho a la justicia desde dos aspectos, opuestos en cuanto a sus posiciones y aún subsidiarios entre sí: 1 . Desde la óptica de la víctima, a quien se le debe garantizar acceso irrestricto y efectivo al aparato jurisdiccional, el cual debe velar por una justicia presta para actuar a plenitud de sus alcances, abarcando todo lo que de ella se espera, aun cuando supere las expectativas de las víctimas, y brindándole a las mismas protección para que sus derechos no sigan siendo vulnerados; 2. Las obligaciones que recaen sobre los Estados para usar de manera efectiva su aparato jurisdiccional, garantizando investigación, juzgamiento, inclusión de víctimas, reparación e intervención en los procesos penales donde tengan un interés legítimo.

El derecho a la justicia también está consagrado en los artículos 8 y 25 de la Convención Americana Sobre Derechos Humanos.

Como se mencionaba anteriormente, el derecho internacional -y por ende, las Cortes Internacionales como la Corte Penal Internacional y la Corte Interamericana de Derechos Humanos- han sido establecidas para -entre otras- impartir justicia donde los Estados no logran (o no desean) lograr su cometido.

Valga decirlo, existen casos de aquiescencia del Estado colombiano, no solamente frente a los hechos ocurridos, sino a la posterior inutilidad del aparato jurisdiccional para impartir verdadera justicia.

Es así, como en los hechos que motivaron la sentencia proferida en el caso de la "Masacre de Mapiripán vs Colombia", del 15 de septiembre de 2005, la Corte Interamericana de Derechos Humanos hizo alusión al Informe de Fondo No. 38/03, proferido por la Comisión Interamericana de Derechos Humanos, de acuerdo con el cual: 
“(...) la República de Colombia es responsable por la violación de los derechos a la vida, integridad y libertad personales de las víctimas de la masacre perpetrada en Mapiripán entre el 15 y el 20 de julio de 1997, consagrados en los artículos 4, 5 y 7 de la Convención Americana. Asimismo, el Estado es responsable de la violación del derecho al debido proceso y la protección judicial de las víctimas y sus familiares, previstos en los artículos 8 y 25 de la Convención Americana, así como del incumplimiento de su obligación de asegurar el respeto de los derechos previstos en dicho Tratado, en virtud de su artículo 1".

Prosiguiendo con sus consideraciones, y previa evaluación de las intervenciones, pruebas y alegatos presentados por las partes, la Corte señaló en el caso que se reseña lo siguiente:

"295. La Corte ha establecido en esta Sentencia que la investigación conducida por Colombia sobre la masacre en Mapiripán ocurrida entre el 15 y el 20 de julio de 1997 incumple los estándares de acceso a la justicia y protección judicial establecidos en la Convención Americana (supra párr. 241). En particular, la Corte señaló que las violaciones declaradas a los derechos a la libertad personal, integridad personal y vida de las víctimas, resultan agravadas como consecuencia de las faltas al deber de protección y al deber de investigar los hechos, así como de la falta de mecanismosjudiciales efectivos para dichos efectos y para sancionar a todos los responsables de la masacre de Mapiripán. De tal manera, el Tribunal declaró al Estado responsable de la violación de los artículos 8.1 y 25 de la Convención, en relación con el artículo 1.1 de la misma.

296. La Corte ha valorado los resultados parciales del proceso penal. No obstante, más de 8 años después de ocurrida la masacre prevalece la impunidad parcial y la falta de efectividad del proceso penal, que se reflejan en dos aspectos: en primerlugar, la mayoría de los responsables no han sido vinculados a las investigaciones o no han sido identificados ni procesados. En segundo lugar, la impunidad se refleja en el juicio y condena en ausencia de paramilitares que se han visto beneficiados con la inefectividad de la sanción (supra párrs. 230, 240 y 96.126$) "$.

La relevancia del derecho a la justicia, en cuanto a que es necesaria para llegar a la verdad, es tangible, actual e inseparable. Prueba de ello la encontramos en noticias de actualidad, como el impactante "pacto de silencio" denunciado por la Corte Suprema chilena, la cual señala que -a pesar de haber transcurrido ya 41 años desde que ocurrió el golpe de estado que derrocó al líder de izquierda Allende y sembró una senda de terror plagada de desaparecimientos forzados, genocidio, homicidios y torturas- a la fecha siguen encubriéndose las responsabilidades de varios oficiales implicados en los hechos, los cuales no han podido ser satisfactoriamente procesados por falta de pruebas.

Otro caso, sobre el cual recurriremos insistentemente por su sensibilidad y relevancia, es el de la masacre de Mapiripán, sobre el cual, el mismo Estado colombiano (en concepto tanto de la Comisión, como de la Corte Interamericana de Derechos Humanos), demostró una abierta disposición encaminada al indulto, el desconocimiento de los derechos de las víctimas, y de la sociedad en general. 
“i) son escasas las perspectivas de justicia en este caso sin la oportuna intervención de la Corte, ya que actualmente existe un fuerte esfuerzo por el gobierno nacional para desmovilizar los paramilitares sin garantía de los derechos a la verdad, la justicia y la reparación. Sólo catorce personas se encuentran vinculadas a la investigación penal de los hechos; los otros autores materiales cuyas identidades se desconocen podrán beneficiarse del programa de desmovilización en el marco del Decreto 128 de 2003. Asimismo, líderes paramilitares, como Carlos Castaño, podrán ser indultados pese sus condenas, si fuera aprobado el proyecto de ley presentado el pasado agosto de 2003 -el cual debe ser estudiado por la Corte-sobre "la reincorporación de los miembros de grupos armados [al margen de la ley] que contribuyan de manera efectiva a la consecución de la paz nacional". El marco legal que rige la desmovilización actualmente, así como el que se crea, asegura la impunidad para la mayoría de estas personas, al negar a las víctimas de violaciones a los derechos humanos el acceso a un recurso efectivo ante jueces o tribunales competentes. Al permitir que los responsables de Mapiripán reciban beneficios jurídicos, el Decreto constituye un impedimento legal a la investigación". Corte Interamericana de Derechos Humanos. Caso de la "masacre de Mapiripán" vs Colombia. 15 de septiembre de 2005.

\subsection{DERECHO A LA REPARACIÓN}

En lo que toca al derecho a la reparación, el mencionado informe de Joinet lo desarrolla de la siguiente manera:

40. El derecho a reparación implica tanto medidas individuales como medidas generales y colectivas.

41. En el plano individual, las víctimas, ya sean víctimas directas, parientes o personas a cargo, deben beneficiarse de un recurso eficaz. Los procedimientos aplicables deben ser objeto de una publicidad lo más amplia posible. El derecho a reparación debe cubrir la integralidad de perjuicios sufridos por la víctima. De acuerdo a la Estructura de principios y directivas fundamentales concernientes al derecho a reparación de las víctimas de violaciones flagrantes de los derechos humanos y del derecho humanitario establecidos por M. Theo van Boven, Ponente especial de la Subcomisión (E/CN.4/Sub.2/1996/17), este derecho comprende los tres tipos de medidas siguientes:

a) Medidas de restitución (tendentes a que la víctima pueda volver a la situación anterior a la violación);

b) Medidas de indemnización (perjuicio síquico y moral, así como pérdida de una oportunidad, daños materiales, atentados a la reputación y gastos de asistencia jurídica); y

c) Medidas de readaptación (atención médica que comprenda la atención psicológica y psiquiátrica). 
42. En el plano colectivo, las medidas de carácter simbólico, a título de reparación moral, tales como el reconocimiento público y solemne por parte del Estado de su responsabilidad, las declaraciones oficiales restableciendo a las víctimas su dignidad, las ceremonias conmemorativas, las denominaciones de vías públicas, los monumentos, permiten asumir mejor el deber de la memoria. En Francia, por ejemplo, ha sido necesario esperar más de 50 años para que el jefe del Estado reconociese solemnemente, en 1996, la responsabilidad del Estado francés en los crímenes contra los derechos humanos cometidos por el régimen de Vichy entre 1940 y 1944. También citaremos las declaraciones de la misma naturaleza realizadas por el Presidente Cardoso en lo que concierne a las violaciones cometidas en Brasil bajo la dictadura militar. Y recordaremos especialmente la iniciativa del Gobierno español de reconocer la calidad de antiguos combatientes a los antifascistas y brigadistas que, durante la guerra civil, han luchado en el campo republicano.

De manera que, tal como el mismo informe lo presenta, este derecho se dimensiona en planos de individualidad y colectividad, centrando los derechos en la restitución, o vuelta de cosas a su estado anterior, la indemnización por los perjuicios causados, así como medidas de readaptación, necesarias por cuanto el espíritu del derecho internacional en este aspecto puntual- se centra en las medidas de satisfacción debidas a quienes han padecido de los delitos más atroces.

Atendido lo anterior, también podemos deducir que este derecho está orientado más a un ámbito individual que para la sociedad en general, por cuanto solamente atañe a las víctimas en cuanto a la parte económica, de restablecimiento de sus bienes y de tratamiento en caso de que sea necesario rehabilitación por parte de psicólogos o psiquiatras.

La parte colectiva, sí podría extenderse hacia la sociedad, por cuanto aúna aquellas reparaciones simbólicas, tales como actos de contrición, monumentos y señales perdurables que permitan mantener viva en la memoria la ocurrencia de los hechos, de manera que no se olviden sus motivos, incidencias y consecuencias para las generaciones actuales y las futuras.

Todas estas medidas fueron tomadas en la ya mencionada sentencia proferida por la Corte Interamericana de Derechos Humanos en el caso Masacre de Mapiripán vs Colombia, ordenando seguimiento a los procesos contencioso administrativos relacionados con los hechos, vigilancia del pago de indemnizaciones y compensaciones ordenadas a los familiares de las víctimas, seguimiento a las acciones estatales para la búsqueda, individualización e identificación de las víctimas y sus familiares, llevar un registro de los familiares que se vayan identificando, con quienes se mantendrá en contacto continuo para asegurarse que no sean objeto de amenazas, más aún después de que hayan recibido las indemnizaciones correspondientes, diligencias necesarias para que se haga efectivo 
el tratamiento debido a los familiares de las víctimas, coordinar las acciones necesarias para que los familiares de las víctimas, así como otros ex pobladores de Mapiripán, que se hayan visto desplazados, puedan regresar en condiciones de seguridad a Mapiripán, en caso de que así lo deseen; disponer una medida de reparación que busque reducir los padecimientos psicológicos de todos los familiares de las víctimas ejecutadas o desparecidas mediante tratamiento gratuito brindado por el Estado; garantía de seguridad a quienes deseasen regresar al pueblo donde ocurrieron los hechos; disculpa pública y reconocimiento de responsabilidad internacional por parte del Estado; la construcción de un monumento puesto en un lugar público y adecuado para preservar la memoria histórica; capacitación en derechos humanos para las fuerzas estatales y; publicación de partes pertinentes de la sentencia en medios masivos de comunicación y en el Diario Oficial.

\subsection{GARANTÍA DE NO REPETICIÓN}

El derecho o garantía de no repetición data desde la creación de la Organización de Naciones Unidas (ONU) quien desde su fundación tiene la obligación de velar por la no repetición de crímenes, atrocidades y guerras a nivel mundial; en tal sentido acogió en el año de 1985 la "Declaración sobre los principios fundamentales de justicia para las víctimas de delitos y del abuso de poder", el cual sirvió de referente para la normatividad que se ha expedido en Colombia en dicha materia.

Los principios señalados en puntos anteriores, es decir, la verdad, la justicia y la reparación, son los pilares fundamentales de la justicia transicional, apuntando a proteger los derechos de las victimas especialmente en forma individual, pero adicionalmente se requiere un cuarto elemento o garantía de no repetición que busca además, proteger a la sociedad en general hacia el futuro; actuando en un doble escenario, a nivel de la víctima al velar por su no re victimización y frente a la sociedad, al imponer al Estado la obligación de recomponer la democracia y construir la Paz.

Razón por la cual se asigna el deber de aplicar todas las medidas legales y/o políticas que permitan lograr tal fin, deber que a su vez se traduce en la imperiosa necesidad de desarticular los grupos armados al margen de la Ley que delinquen en el respectivo territorio y que son considerados como causantes del flagelo de la sociedad.

Concepto que sostiene Luis Joinet quien como relator de derechos humanos, en los años de 1997 y 2005, luego de la formulación del conjunto de principios para el respeto de los derechos humanos en contra de la impunidad de las naciones unidas, ya referenciados en páginas anteriores, manifestó: 
"Las reformas institucionales encaminadas a prevenir una repetición de las violaciones deben establecerse mediante un proceso de amplias consultas públicas, incluida la participación de las víctimas y otros sectores de la sociedad civil" (Joinet\&Orentlicher, 1997, 2005, Principio 35).

Dichas reformas y medidas hacen referencia específicamente a emprender procesos que pueden enmarcarse dentro de una transición, pero con la presencia necesaria de transformacionestalescomo:1. Reforma delasinstitucionesestatales,2.Desmantelamiento de las fuerzas armadas paraestatales, 3. Desmovilización y reintegración social, 4 . Reforma de las leyes e instituciones que contribuyen a la impunidad (Joinet \& Orentlicher, 1997, 2005, Principios 36-38)".

Es así como la política de reintegración social responde a una de las máximas de la justicia transicional, ya que a partir de ella se generan las condiciones para reintegrar a los grupos armados organizados al margen de la ley a la vida civil, a la legalidad, generando condiciones sociales, económicas y políticas que permiten la vida del desmovilizado en comunidad y a su vez garantizan la no repetición de los hechos victimizantes al rehabilitar a las personas objeto de esta política y al desarticular las organizaciones criminales.

Sin una real y efectiva política de reintegración social y económica que brinde las garantías suficientes en el marco constitucional y legal (ya sea el vigente o el nuevo régimen que se establezca) no es posible el éxito de la justicia transicional, pues es necesario planear, formular y ejecutar políticas que permitan recomponer el núcleo de la sociedad, que permitan la educación de los nuevos civiles, su preparación para el empleo, su tecnificación, y en especial impedir que vuelvan a delinquir, evento que de presentarse seria el fracaso de política pública nacional.

En Colombia, a través del programa de Desarme, Desmovilización y Reintegración Social se ha logrado apuntar de manera acertada (si así puede llamársele) al cumplimiento de la garantía de no repetición con el inicio de los diálogos de paz con grupos de diferente naturaleza (paramilitar, guerrilla insurgente), procesos que no serán abordados en profundidad al no ser objeto de nuestra investigación.

Es importante traer a colación, el siguiente postulado, que obedece a la formulación que en su momento realizó la Ley 975 de 2005 o ley de justicia y paz en relación a la garantía de no repetición:

Artículo 48. Medidas de satisfacción y garantías de no repetición. Las medidas de satisfacción y las garantías de no repetición, adoptadas por las distintas autoridades directamente comprometidas en el proceso de reconciliación nacional, deberán incluir: 
1. La verificación de los hechos y la difusión pública y completa de la verdad judicial, en la medida en que no provoque más daños innecesarios a la víctima, los testigos u otras personas, ni cree un peligro para su seguridad.

2. La búsqueda de los desaparecidos o de las personas muertas y la ayuda para identificarlas y volverlas a inhumar según las tradiciones familiares y comunitarias. Esta tarea se encuentra principalmente a cargo de la Unidad Nacional de Fiscalías para la Justicia y la Paz.

3. La decisión judicial que restablezca la dignidad, reputación y derechos de la víctima y las de sus parientes en primer grado de consanguinidad.

4. La disculpa, que incluya el reconocimiento público de los hechos y la aceptación de responsabilidades.

5. La aplicación de sanciones a los responsables de las violaciones, todo lo cual estará a cargo de los órganos judiciales que intervengan en los procesos de que trata la presente ley.

6. La sala competente del Tribunal Superior de Distrito judicial podrá ordenar conmemoraciones, homenajes y reconocimiento a las víctimas de los grupos armados al margen de la ley. Adicionalmente, la Comisión Nacional de Reconciliación y Reparaciones podrá recomendar a los órganos políticos o de gobierno de los distintos niveles, la adopción de este tipo de medidas.

7. La prevención de violaciones de derechos humanos.

8. La asistencia a cursos de capacitación en materia de derechos humanos a los responsables de las violaciones. Esta medida podrá ser impuesta a los condenados por la sala competente Tribunal Superior de Distrito Judicial.

En estricto sentido, solo los numerales siete y ocho corresponden a la satisfacción de la garantía de no repetición; los demás refieren a los principios de verdad, justicia y reparación, no obstante, es preciso señalar que dicha imprecisión no se mantiene, en tanto que el mencionado artículo fue derogado por el artículo 41 de la Ley 1592 de 2012, así las cosas, no se encuentra vigente en nuestro ordenamiento jurídico.

No obstante, el artículo 149 de la Ley 448 de 2011, en relación a las medidas que deberá adoptar el Estado, como garantía de no repetición; y en relación al tema que nos ocupa, establece: “a). La desmovilización y el desmantelamiento de los grupos armados al margen de la Ley;... e). La creación de una pedagogía social que promueva los valores constitucionales que fundan la reconciliación, en relación con los hechos acaecidos 
en la verdad histórica;... I). La reintegración de niños, niñas y adolescentes que hayan participado en los grupos armados al margen de la ley; m). Diseño e implementación de estrategias, proyectos y políticas de reconciliación de acuerdo a lo dispuesto en la Ley 975 , tanto a nivel social como en el plano individual;... r). La derogatoria de normas o cualquier acto administrativo que haya permitido o permita la ocurrencia de las violaciones contempladas en el artículo $3^{\circ}$ de la presente Ley, de conformidad con los procedimientos contencioso-administrativos respectivos".

Así las cosas, se observa que los procesos de desmovilización, la reconciliación, la reintegración de los miembros de los grupos al margen de la ley, obedecen al deber del Estado de garantizar a las víctimas y a la sociedad la no repetición de los hechos victimizantes, en virtud del cual se produce la política pública nacional.

De igual manera el parágrafo del citado artículo señala, que es a través del plan nacional de atención a las víctimas que se debe reglamentar las garantías de no repetición mediante el fortalecimiento de los diferentes planes y programas que conforman la política pública de prevención y protección de las violaciones que contempla la misma ley 1448 de 2011 en su artículo tercero.

Por último y no menos importante, la ley 448 establece en articulo seguido el deber del Estado de desmantelar las estructuras económicas y políticas que se han beneficiado y que han dado sustento a los grupos armados al margen de la ley, con el fin de asegurar la realización de las garantías de no repetición.

En resumen, la garantía de no repetición conlleva en sí, la obligación del Estado de evitar que se produzcan todos aquellos crímenes o graves violaciones de derechos humanos y al derecho internacional humanitario, que dieron pie a la aplicación de los postulados de la justicia transicional; en otras palabras busca garantizar el pleno goce efectivo de los derechos de la población y consecuentemente, logra cumplir con los compromisos internacionales, adquiridos mediante protocolos y convenios de la misma naturaleza; estableciendo de esta forma una intrínseca relación entre la justicia transicional, la política pública de reintegración social y por supuesto con el derecho administrativo, como rama que regula la organización y la actividad de la administración pública.

\section{CONCLUSIONES}

1. La Constitución Política de Colombia consagró en su artículo 22 la Paz como un derecho y un deber de todo colombiano, y a partir de este concepto se desarrollan todas las políticas del gobierno nacional, en respuesta a los conflictos que se presentan actualmente. La paz se constituye entonces en el fin último de las políticas nacionales en materia de inclusión social, reintegración, justicia transicional, derechos humanos y derecho internacional humanitario. 
En esta apuesta por construir la paz, es necesaria la expedición de normas jurídicas de distinta naturaleza, llámese leyes, decretos, resoluciones o acuerdos; con los que se formalizan las decisiones tomadas por el alto gobierno y se busca materializar la política pública, regulando las relaciones sociales y estableciendo nuevos parámetros - en la mayoría de los casos - frente al actuar y que hacer de la administración pública, como órgano obligado a proteger los derechos de los ciudadanos y encargado de administrar la cosa pública.

De esta forma el derecho administrativo se interrelaciona con otros conceptos básicos como la paz, el postconflicto y por supuesto la justicia transicional. Para el éxito de esta última se requiere cumplir entre otros con la garantía de no repetición, en virtud del cual se desarrolla la política pública de reintegración social y económica de los grupos armados al margen de la ley, con el fin de evitar que se presenten nuevamente los hechos victimizantes que generaron el conflicto.

En suma la relación que se presenta entre el derecho administrativo, la justicia transicional y las políticas públicas, se refleja - en el surgimiento de un conflicto que afecta a la sociedad (sociedad regulada por normas en su mayoría de enfoque público y administrativo), la búsqueda de soluciones al conflicto con la aplicación de los postulados de la justicia transicional, - la aparición de la garantía de no repetición como componente esencial de la justicia, - la necesidad de iniciar procesos de desmovilización y reintegración social que garanticen la no repetición y tranquilidad general, - la formulación de una política pública estatal para adelantar los procesos de reintegración, - basados en las normas propias del derecho administrativo.

2. La necesidad de conseguir la paz, supone la consecuente necesidad de formular políticas de gobierno acorde a los cambios que se producen, tanto en el orden nacional como territorial. En tal sentido, en Colombia se han formulado políticas de alto impacto en materia de inclusión social y en especial a lo que el tema de víctimas se refiere, buscando la reivindicación de sus derechos, y la construcción de un nuevo tejido social; todas ellas apuntando a cumplir con los lineamientos de la ley 975 de 2005 y 1448 de 2011 como máximos referentes en materia transicional en Colombia.

La política pública de paz, comprende un marco normativo que se perfila hacia el resarcimiento de los daños causados por el conflicto armado interno, y propende por brindar satisfacciones no solamente a las víctimas, sino a la sociedad en general.

Desde el papel, el Gobierno Nacional proyecta una imagen de control tanto fiscal como legal e institucional respecto de la búsqueda de la paz, tomando acciones que desde el compendio normativo, documentos CONPES, y concatenadas con las apropiaciones y esfuerzos fiscales efectuados para solventar el proceso de justicia transicional iniciado, 
nos indican que hay un planteamiento coherente respecto de las acciones a tomarse para llegar al fondo de lo pretendido. No obstante, es dable manifestar que lo anterior no cierra la puerta al alza de tributos en detrimento de las finanzas de los ciudadanos si los recursos para atender el postconflicto resultan insuficientes.

3. La política pública creada para facilitar la reintegración social y económica de los grupos armados al margen de la ley, creada mediante CONPES 3554 de 2008, contrario censu, a lo que ocurre con el resto de políticas que conforman el paquete para la paz, no ha sido objeto de magnas reformas o transformaciones, frente a sus planes, programas y proyectos. Para el periodo analizado solo se observaron las siguientes reformas de tipo legal:

- Decreto 3011 de 2013, que en su artículo 95 y siguientes regula el proceso de reintegración para los postulados a la ley de justicia y paz, la necesidad de un programa de reintegración especial y el respectivo monitoreo y seguimiento al mismo, es de resaltar que este decreto fue expedido en reglamentación de la ley 975 de 2005, 1448 de 2011 y 1592 de 2012.

- Resolución 754 de 2013 proferida por la Agencia Colombiana de Reintegración Social, mediante el cual se reglamentan los requisitos, características, condiciones y obligaciones para el acceso y otorgamiento de los beneficios sociales y económicos del proceso de reintegración a la sociedad civil dirigida a la población desmovilizada; procedimiento de suspensión, pérdida de los mismos y culminación del proceso de reintegración.

- Ley 1738 de 2014,Por medio de la cual se prorroga por cuatro años más, la Ley 418 de 1997, prorrogada y modificada por las Leyes 548 de 1999, 782 de 2002, 1106 de 2006 y 1421 de 2010. En ella se consagran unos instrumentos para la búsqueda de la convivencia, la eficacia de la justicia y se dictan otras disposiciones, tales como los beneficios en salud, educación, vivienda y jurídicos que se le conceden al excombatiente que se acoge a los programas de reintegración. Si bien es cierto, para este caso no se crea un nuevo derecho ni modifica los programas existentes, establece una prorroga por cuatro más, en el entendido que coadyuva en la búsqueda de la convivencia pacífica.

- Ley 1475 de 2014, por medio del cual se fija el marco para la paz. A pesar que esta norma no toca directamente el tema de la reintegración social, aprueba el uso del referendo para avalar los acuerdos de paz, a partir de él se legitimaran todas decisiones frente a las nuevas políticas públicas que adoptará el gobierno nacional para el postconflicto. 
- Documento CONPES 3813 de 2014 que establece el marco fiscal a mediano plazo para el periodo 2015 - 2018, y en tal sentido, en relación con la política de reintegración social señala como techo fiscal: 9.972 miles millones de pesos para el año 2015, 9.886 miles millones de pesos para el año 2016, 10.351 para el año 2017 y 10.917 miles millones para el año 2018.

- Documento CONPES 3814 de 2014 que establece el plan operativo anual de inversiones para el año 2015 y en relación a las inversiones de interés señala que “al Sector Inclusión Social y Reconciliación: Se asignaron \$8,7 billones, 18,9\% del total de recursos de inversión, los cuales contemplan tanto los recursos propios por \$1,09 billones, como los recursos del CREE por \$2,59 billones del Instituto Colombiano de Bienestar Familiar - ICBF. La asignación de estos recursos tuvo en cuenta la prioridad de atender programas sociales como; Familias en Acción (\$2,26 billones), Primera Infancia ( $\$ 3,05$ billones) y Red Unidos $(\$ 0,18$ billones)".

- Resolución 1724 de 2014 proferida por la Agencia Colombiana de Reintegración Social, en la que reglamentan requisitos, características, condiciones y obligaciones para el acceso y otorgamiento de los beneficios sociales y económicos del Proceso de Reintegración dirigido a la población desmovilizada y postulada a la Ley 975 de 2005, modificada y adicionada por la Ley 1592 de 2012 y el Decreto Reglamentario 3011 de 2013.

- Decreto 1649 de 2014 por el cual se modifica la estructura del Departamento Administrativo de la Presidencia de la República, se establecen las funciones para el Ministro Consejero para el Postconflicto, Derechos humanos y Seguridad. Al respecto, su artículo 25 señala: "Asesorar al Presidente de la República en la formulación, estructuración y desarrollo de las políticas y programas para la reintegración de los grupos armados ilegales en coordinación con la Agencia Colombiana para la Reintegración de Personas y Grupos Alzados en Armas y de la Oficina del Alto Comisionado para la paz", de igual forma establece la obligación de hacer seguimiento y verificación de los programas que se crean para el postconflicto. Según la nueva estructura este ministerio está conformado por la Consejería Presidencial para los Derechos Humanos, la Dirección para la Acción Integral contra Minas Antipersonales, La Dirección de Seguridad y La Dirección para el Postconflicto.

- Decreto 1650 de 2014por el cual se modifica el sistema de nomenclatura, clasificación y remuneración de los empleos del Departamento Administrativo de la Presidencia de la República. Si bien es cierto, esta norma no contempla disposiciones en relación a las políticas públicas y a la reintegración social y económica de los grupos armados al margen de la ley, hace parte del grupo normativo expedido por el gobierno nacional para dar aplicación a los planes, programas y proyectos previstos para el postconflicto. 
- Decreto 1651 de 2014 por medio del cual se modifica la planta de personal del Departamento Administrativo de la Presidencia de la Republica. En él se crea el cargo de Ministro Consejero del Presidente de la República (2) código 1185. De esta forma se viabiliza el cargo del ministro para el postconflicto, que se ocupará como se señaló anteriormente de las políticas públicas.

- Cursó en el congreso de la republica una de las reformas más importantes a la estructura del Estado y que toca directamente con el proceso de reintegración social, en el año 2013, el cual hace referencia a la posible creación del Ministerio de la Seguridad Ciudadana, el cual se encargaría de ejecutar todo el proceso de reinserción y ubicación de las personas que se sometan a la legalidad después de la dejación de las armas. Se propone la reorganización del Ministerio de Defensa y la supresión de La Subdirección de Seguridad y Convivencia Ciudadana del Ministerio de Interior y de La Agencia Colombiana para la Reintegración. El proyecto fue archivado.

Ahora bien, no obstante, el cumplimiento que sobre las proyecciones, planes y programas se ha presentado en Colombia (a la luz de lo expuesto por entes de control), dicha política se formuló en curso de un escenario social, económico y de conflicto armado disímil al actual y al escenario de postconflicto; el referido CONPES ha guiado la política de reintegración social en vigencia de dos planes nacionales de desarrollo que a pesar de conservar puntos de encuentro obedecen a dos políticas de gobierno distintas.

Los programas y proyectos que adelanta la Agencia Colombiana de Reintegración Social en apoyo de la demás entidades que conforman la política de reintegración son aptos para el hoy día, en el que las desmovilizaciones se presentan una a una y por consiguiente la atención es gradual, pero resultan insuficientes por su naturaleza temporal y coyuntural para atender la población que se espera se desmovilice luego de firmado el acuerdo de paz, se requiere entonces de una reforma sustancial a la política pública nacional de reintegración social, a tono con las actuales necesidades y problemas sociales, y los retos de la política a mediano y largo plazo, que implemente acciones en beneficio de una población que de ser mal atendida o no reincorporada a la sociedad sería la causante del incremento de la violencia en nuestras ciudades.

Así las cosas, y dado que para que las causas del conflicto (por lo menos las que se piensan atender en los diálogos de paz actuales) puedan verse al menos parcialmente solventadas habrá que adelantar significativos y cuantiosos cambios no solo en materia penal, sino también en materia legislativa, administrativa y social que permitan la modificación de la estructura del Estado, materializando la garantía de no repetición y permitiendo la real y verdadera reintegración de los miembros de grupos armados con los demás actores sociales. 


\section{RECOMENDACIONES}

1. Estudio, formulación y ejecución de una nueva política pública de reintegración social acorde a los estándares de la justicia transicional que se aplica en el actual proceso de paz y a las necesidades y problemas sociales actuales que se pretenden resolver con su puesta en marcha.

Política que concilie los interés de la sociedad con los intereses de los grupos armados, basada en programas permanentes y no temporales que permitan la verdadera resocialización del excombatiente y su inclusión social.

2. Llevar a cabo un análisis económico sustentado en las reglas actuales de la economía sobre los costos de los programas y proyectos que se pretendan a ejecutar para lograr la sostenibilidad de la política y evitar crisis en la prestación de los distintos servicios.

3. La política pública de reintegración social y económica para miembros de grupos armados al margen de la ley, debe apuntar a la inclusión social de los excombatientes procurando cambios estructurales en los organismos del Estado - Diferentes al sector defensa y seguridad nacional - que faciliten su vinculación laboral y su consecuente productividad en la vida civil.

4. Se debe diseñar la política teniendo en cuenta el factor diferencial, aspecto fundamental en la atención según la ley 1448 de 2011. Es básico este aspecto, pues dentro de los grupos armados se encuentran miembros de grupos étnicos y/o negros. Así las cosas se deben implementar acciones que garanticen el enfoque diferencial, protocolos de atención de carácter diferencial para las entidades a cargo del proceso, tal como sucede para el caso de los menores de edad hoy en día.

5. Establecer las obligaciones institucionales frente a la necesidad de preservar los entornos seguros, en los que se evita cualquier daño físico, moral o sicológico para los excombatientes, y de forma consecuente para la sociedad. Siempre conservando la institucionalidad el poderío y manejo de las armas y la política de seguridad; sin delegar la seguridad en los excombatientes.

6. El diseño y formulación de la nueva política pública debe buscar cerrar brechas sociales y lograr los mejores escenarios para una paz duradera, en tal sentido se recomienda para lograr la inclusión social y laboral, crear incentivos en reducción de impuestos a los grupos familiares u hogares que vinculen como empleado (jardinero, servicio doméstico, niñera, conductor, entre otros) a personal desmovilizado. De la misma forma a las empresas que incorporen dicho personal. 
7. Reformar los estatutos de contratación pública en Colombia, para que se establezca en los procesos de licitación pública,puntajes adicionales de calificación a los oferentes que certifiquen que dentro de su nómina se ha incluido un porcentaje de desmovilizados, en especial para temas de obra pública siempre que demuestren experticia o conocimientos sobre el tema.

8. Es necesario que al interior de las entidades con participación y responsabilidad dentro del proceso de reintegración social, se creen unidades o grupos especiales para atención del personal y sus necesidades, que garantizar la inclusión en los diferentes programas y la prestación de los servicios.

9. urge para la reintegración, una reforma al sistema de salud, crear de ser posible un subsistema, pues serán muchos más los beneficiarios por atender y se deberá buscar estructuralmente mejorar la calidad del servicio, evitando que colapse el sistema y se desmejore la atención del resto de la población.

10. La nueva política debe definir la forma en que se permitirá la participación política de los excombatientes, el cual resulta ser un presupuesto clave para la reintegración social y económica, lo que demanda cambios en la ley electoral vigente y por supuesto de nuestra Constitución Política.

11. Para todos los casos se requiere ampliación de presupuesto, pues las entidades estarán Ilamadas a responder a las necesidades de mayor número de población, ello requiere adicionalmente un estudio juicioso por departamentos, para determinar la ubicación de los reintegrados a la vida civil de acuerdo a la oferta social y laboral prevista, esto permitirá en gran medida el éxito de la política y el cumplimiento por parte del Estado de la garantía de no repetición.

\section{REFERENCIAS BIBLIOGRÁFICAS}

Bardach, Eugene (2010). Los ocho pasos para el análisis de las políticas públicas. Centro de investigación y docencia económicas. Ed. CIDE. México D.F., P 17 y sig.

Castellanos, Ethel (2005). Verdad, Justicia y Reparación en Argentina, El Salvador y Sudáfrica. Perspectiva Comparada. Estudios Socio Jurídicos. Bogotá, P 200-249.

CONPES 3554 de 2008. Ob cit. P 25. P 68.

Contraloría General de la República. (2010-2014). Informe de auditoría a políticas públicas. Política pública de reintegración para desmovilizados. P 16

Corte Constitucional. (2013). Sentencia SU - 254 de 2013. 
Corte Constitucional. Sentencia T-025 de 2004. M. P. Dr. Manuel José Cepeda Espinosa. Bogotá, D. C., veintidós (22) de enero de dos mil cuatro (2004).

Corte Constitucional. Sentencia C-052 de 2012. M. P. Dr. Nilson Pinilla Pinilla. Bogotá, D. C., ocho (8) de febrero dedos mil doce (2012).

Corte Constitucional. Sentencia C-370 de 2006. M. P. Dr. Manuel José cepeda espinosa, Dr. Jaime Córdoba Triviño, Dr. Rodrigo Escobar Gil, Dr. Marco Gerardo Monroy Cabra, Dr. Alvaro Tafur Galvis, Dra. Clara Inés Vargas Hernández. Bogotá, D.C., dieciocho (18) de mayo de de dos mil seis (2006).

Corte Constitucional. 2006. Sentencia C - 575 de 2006. M. P. Dr. Álvaro Tafur Galvis. Bogotá D.C., veinticinco (25) de julio del año dos mil seis (2006).

Corte Constitucional. Sentencia C - 579 de 2013. M. P. Jorge IgnacionPreteltChaljub. Bogotá, D.C., veintiocho (28) de agosto de (2013).

Corte Constitucional. Sentencia C-711 de 2011. M. P. Dr. Nilson Pinilla Pinilla. Bogotá, D.C.

Corte Constitucional. Sentencia SU 254 de 2013. M. P. Dr. Luis Ernesto Vargas Silva. Bogotá, D.C., veinticuatro (24) de abril de dos mil trece (2013).

Echavarría Olarte G. (2012). Revista FACULTAD DE DERECHO Y CIENCIAS POLÍTICAS. Vol. 42, No. 116, p 12.

Elster, Jon. (2006). Rendición de cuentas, la justicia transicional en perspectiva histórica. Ed. Katz. Buenos Aires. P 17.

Forer, Andreas. (2012). Colección El saber penal. Bogotá D.C. Grupo editorial Ibañez. P 19.

Gómez Dávila, N. (2007).Escolios escogidos. Ed. Los papeles del sitio. Valencia, España. P 69.

Hinestrosa Rey, R. (2007). Ensayos sobre políticas públicas (prefacio). Universidad Externado de Colombia. Bogotá D.C., P. 9.

Ibídem. P 11. (s.f.)

Ídem. P 1. P 9.P 18. (s.f.)

López Díaz, C; González, D; Errandonea, J. (2011). Justicia transicional en Colombia. Colombia: un nuevo modelo de justicia transicional. Embajada de la República Federal de Alemania. Bogotá D.C. 
Mora Insuasty, S. (2008). La ley de justicia y paz en el marco de la Convención Americana de Derechos Humanos. Bogotá D.C. Ed. Nueva Jurídica. P 23.

Sura. 9:123; 2:190; 22:39. (s.f.)

Orozco Abad I. (2009).Justicia transicional en tiempos del deber de memoria. Bogotá D. C. Editorial TEMIS S.A. P 1.Ob. Cit. p 9.Ob. Cit. p 11.

Parada, R. (2012). Concepto y Fuentes del Derecho Administrativo. Madrid España. Editorial Marcial. P 13. P 15.

Pérez Romero, J. (1999). Derecho Administrativo General. Xxx. Editorial Euned. P.10. P.23.

Rincón T. (2010).Verdad, justicia y reparación. La justicia de la justicia transicional. Universidad del Rosario. P 27. P 55.

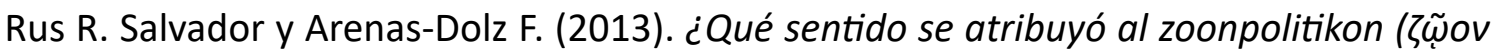

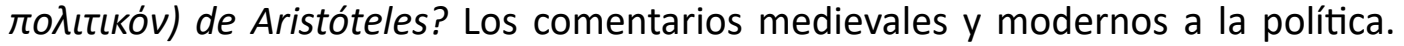
Proyectos de Investigación Científica y Desarrollo Tecnológico FFI2010-21639-C02-01 y FFI2012-35734, financiados por el Ministerio de Economía y Competitividad del Gobierno de España y con Fondos FEDER de la Unión Europea. P 95.

Torregrosa Jiménez, R. (2011).Representaciones sociales de la justicia transicional en la revista Semana. Bogotá D.C. Ed. Universidad Libre. P11.

Torregrosa Jiménez, R. y Torregrosa Jiménez, N. (2012).Justicia transicional. paz vs justicia. El dilema en Colombia. Universidad Libre. 2012. P 9. P21.

Uprimny Yepes, R., Sánchez Duque, L., Sánchez León, N. (2014). Justicia para la paz. Crímenes atroces, derecho a la justicia y paz negociada. Bogotá D. C. Editorial Dejusticia. P 15.

Vargas Velásquez, A. (1999).Notas sobre el Estado y las políticas públicas. Bogotá D.C. Almudena editores, P 59.

Villar, L. y Forero, D. (2014).Escenarios de vulnerabilidad fiscal para la economía colombiana. Bogotá D.C. FEDESARROLLO, P. 28.

\section{WEBGRAFIA}

http://bienvepaz.wordpress.com/2012/01/30/el-significado-de-la-paz/ 
https://colaboracion.dnp.gov.co/CDT/PND/6C.\%20Cap\%C3\%ADtulo\%20V.pdf

http://colombiainternacional.uniandes.edu.co/view.php/9130/index.php?id=9130

http://enciclopedia.us.es/index.php/Tipos_y_clases_de_guerra

http://escolapau.uab.cat/img/programas/alerta/alerta/10/cap03e.pdf

http://escolapau.uab.es/img/programas/derecho/justicia/seminariojt/tex03.pdf

http://es.wikiquote.org/wiki/Michel_Foucault

http://farc-ep.co/?p=1848

http://ictj.org/es/que-es-la-justicia-transicional

http://ictj.org/es/quienes-somos

http://lema.rae.es/drae/?val=justicia

http://lema.rae.es/drae/?val=paz

http://lema.rae.es/drae/?val=v\%C3\%ADctima

http://pochicasta.files.wordpress.com/2009/03/que-es-sociedad.pdf

http://portalweb.ucatolica.edu.co/easyWeb2/files/54_10841_justicia-y-paz.pdf

http://reliefweb.int/report/colombia/colombia-el-antes-y-el-ahora-de-lapol\%C3\%ADtica-de-reinserci\%C3\%B3n-\%C2\%BFevoluci\%C3\%B3n-o-retroceso

http://restituciondetierras.gov.co/media/descargas/pdf_tomo2/doc30.pdf

http://titan.utadeo.edu.co/comunidad/paz/images/stories/documentos/Serie3.pdf

http://www.amnesty.org/es/international-justice/issues/truth-commissions

http://www.arcoiris.com.co/2012/05/perdonar-lo-imperdonable/

http://www.banrepcultural.org/blaavirtual/geografia/descentr/05.htm

http://www.banrepcultural.org/blaavirtual/memoria-historica-cnrr/despojodetierras.html 
http://www.bdigital.unal.edu.co/10496/1/699820.2013.pdf

http://www.ccncol.org/documentos.shtml

http://www.centrodememoriahistorica.gov.co/

http://www.centrodememoriahistorica.gov.co/descargas/ley_victimas/6222_ABC_ enero_11.pdf

http://www.coljuristas.org/documentos/libros_e_informes/verdad_justicia_y_ reparacion.pdf

http://www.cronicon.net/paginas/edicanter/Ediciones84/Nota10.pdf

https://www.dnp.gov.co/Plan-Nacional-de-Desarrollo/Paginas/Que-es-el-Plan-Nacionalde-Desarrollo.aspx

http://www.elespectador.com/noticias/economia/el-debate-los-predios-ruralesarticulo-522625

http://www.fundacionparalareconciliacion.org/.

http://www.humanas.org.co/pagina.php?p_a=33

http://www.humanrights.com/es_ES/what-are-human-rights.html

http://www.icrc.org/spa/assets/files/other/opinion-paper-armed-conflict-es.pdf

https://www.icrc.org/spa/resources/documents/misc/5tdlnb.htm

http://www.javeriana.edu.co/juridicas/pub_rev/univ_est/pdfs/cap.\%202.pdf

http://www.lostiempos.com/diario/actualidad/internacional/20120917/la-negociacionduro-mas-de-dos-anos_185766_394085.html

http://www.minjusticia.gov.co/Portals/0/Foros\%20Justicia\%20Transicional/LIBRO\%20J. TRANS..pdf

http://www.movimientodevictimas.org/ nuncamas/index.php?option=com_ content\&view $=$ article\&id $=5 \&$ temid $=313$

http://www.ohchr.org/SP/Issues/Pages/WhatareHumanRights.aspx 
http://www.procuraduria.gov.co/portal/media/file/descargas/publicaciones/tomo2_ reinsertados.pdf

http://www.reintegracion.gov.co/

http://www.reintegracion.gov.co/es/agencia/Otros\%20planes/Informe\%20de\%20 auditor\%C3\%ADa\%20a\%20la\%20Pol\%C3\%ADtica\%20de\%20Reintegraci\%C3\%B3n. pdf.

http://www.reintegracion.gov.co/es/agencia/Documentos\%20Informes\%20de\%20 gestin/2014\%20l\%20Informe\%20ejecutivo\%20de\%20gesti\%C3\%B3n.pdf

http://www.reintegracion.gov.co/es/la-reintegracion/Paginas/ruta.aspx

http://www.reintegracion.gov.co/es/la-reintegracion/Paginas/faqs-familiar.aspx http://www.reintegracion.gov.co/es/la-reintegracion/Paginas/faqs-educativa.aspx http://www.reintegracion.gov.co/es/la-reintegracion/Paginas/faqs-ciudadana.aspx http://www.reintegracion.gov.co/es/la-reintegracion/Paginas/faqs-seguridad.aspx http://www.reintegracion.gov.co/es/sala-de-prensa/Campanas/yoprotejo/index.html http://www.reintegracion.gov.co/es/sala-de-prensa/Paginas/especiales.aspx http://www.reintegracion.gov.co/Reintegracion/centro_de_documentacion http://www.reintegracion.gov.co/es/la-reintegracion/Documents/colombia.pdf

http://www.reintegracion.gov.co/Reintegracion/centro_de_documentacion/ reintegracioneconomica/Documents/01.pdf

http://www.reintegracion.gov.co/Reintegracion/centro_de_documentacion/ reintegracioneconomica/Documents/02.pdf

http://www.semana.com/mundo/articulo/aniversario-del-golpe-de-estado-chilenollega-con-noticia-de-pacto-de-silencio-militar/402413-3

http://www.slideshare.net/jcfdezmx2/el-conflicto-y-sus-elementos

http://www.tni.org/sites/www.tni.org/files/download/martinez-ley-de-victimas-web.pdf 
http://www.ugr.es/ cuadgeo/docs/articulos/040/040-009.pdf

h t t p : / / w w w. unh ch r. ch/H u ridocda/ H u ridoca. nsf/0/2710db6e8c956a2d802566aa00524ed2?Opendocument

http://www.viva.org.co/cajavirtual/svc0369/articulo05.html

www.acr.gov.co 